\title{
Policy Implementation Regarding The Duties And Functions Of Village Head In Organizing Village Administration In Peana Village, Pipikoro District, Sigi Regency, Central Sulawesi
}

\author{
Syahruddin Hattab ${ }^{1}$, Daswati ${ }^{2}$, Mustainah $^{3}$
}

\begin{abstract}
Syahruddin Hattab ${ }^{1}$, Department of Public Administration, Faculty of Social and Political Science, Tadulako University, Palu, Indonesia, email: udinhattab60@ gmail.com

Daswati ${ }^{2}$, Department of Public Administration, Faculty of Social and Political Science, Tadulako University, Palu, Indonesia, email: daswatisahar@ gmail.com

Mustainah $^{3}$, Department of Public Administration, Faculty of Social and Political Science, Tadulako University, Palu, Indonesia, email: mustainahmappatoba@yahoo.co.id
\end{abstract}

\begin{abstract}
The Village Government is an institution that functions to organize village administration towards good governance. This study aims to analyze the implementation of the policy on the duties and functions of the village head in administering the administration of the Peana village, Pipikoro district, Sigi regency, Central Sulawesi Province, with reference to the aspects of communication, resources, disposition and bureaucratic structure. This qualitative research is carried out in Peana Village which is geographically isolated with limited infrastructure. Data were obtained from informants which are village officials and the community. Data are collected through observation to observe the behaviour naturally, original and spontaneous within a certain period of time to obtain careful, in-depth and detailed data. The data also obtained from documents originating from books, government regulations in the Peana Village Office as well as interview with the village secretary, village staffs and community members. The results showed that socialization about the content, purpose, direction and target group had not been implemented. Human resources, infrastructure and budget resources were inadequate. Village government disposition in responding to policies is not maximized. Bureaucratic structure in policy implementation, was not guided by standard operating procedure (SOP). The conclusion is that the task and function of the village head in the village administration is not optimally implemented, because the village head has not optimally responded regarding the administration of village administration. For this reason, the researcher recommends that the village head should be more active in responding to his duties and functions with the provided assistance by the academics, so that preparation and planning can be carried out effectively and efficiently.
\end{abstract}

Keywords : Communication, Resources, Disposition, Bureaucratic Structure

\section{INTRODUCTION}

Minister of Home Affairs Regulation Number 47 of 2016 regarding the administration of village government and the Minister of Home Affairs Regulation No. 32 of 2006 regarding the administrative guidelines of the village explained that what is meant by the village administration is the whole process of recording data and information about the administration of village administration in the village administration book, public administration, population, finance, development and society.

The policy proves the importance of the tasks and functions of the Village Head in the development of the village itself, therefore it is expected that the village government has the ability to implement its tasks and functions as stipulated in Law no. 6 of 2014 on Village and Minister of Home 
Affairs Regulation No. 2 of 2017 on the Administration of Village Administration. The village head has the authority, duties, obligations to organize his village's household and perform the duties of the government and local government. This policy is the responsibility of the village government to be implemented accountably, effectively and efficiently. Sudirman (2004) stated that policy is a collection of decisions that determine carefully how the strategy will be implemented or in other words the policy is a guideline for the implementation of certain actions or activities. This means that the policy requires village heads who have a strategy to implement as prescribed, since the village government is an extension agency of the central government that has a strategic role to manage the rural community in order to realize the government's development. Based on these roles, regulations or laws regarding to village governance is publisged, so that the wheels of governance will optimally run.

Managing the village administration at this time is very important where billions of rupiahs disbursed from the government through the APBN (National Income and Expenditure Budget) and APBD (Regional Income and Expenditure Budget) to the village. If the village administration is carried out merely inadvertently this will lead to the preparation of work programs that refer to the government program to build the village to become not fully sustainable. To improve the management of village government, it is necessary to make administrative arrangements to be more effective and efficient, administrative arrangement is the recording of data and information in supporting the implementation of Village Government, it is necessary to do the improvement of the administrative implementation, so that the preparation of village mid-term development plan can be done well, village administration is available then it can facilitate the government in preparing the RPJMD (Regional Medium Term Development Plan).

This research is carried out in hope of finding the answer on whether the Peana Village Head of Pipikoro district, Sigi Regency implements its duties and functions as administrative administrator of village administration effectively and efficiently, namely the administration of public administration books, population administration, financial administration, development administration, and village consultation administration. The reason for choosing the location of the research is because Peana Village is a geographically isolated village and the responsibility of all elements to build the village so that the community's life have the same quality as the community of a developed village.

The theory proposed by Edward III (1984) shows four aspects that play an important role in achieveing successful implementation such as Communication, Resources, Disposition, and Bureaucratic Structure. One aspect that the researchers found was that the capacity of some of the village government's apparatus resources had not responded well to the village administration, had not fully understood and unable to perform the main duties and functions in the administration of the village administration. Supporting infrastructure in the implementation of village administration is not sufficient. Thus, the village data that can support the development planning are inadequate. This may lead to a perception that the lack of availability and accuracy of basic village data needed in planning, implementation and development oversight and considerations in the village strategic decision-making process can make it difficult for the village Medium Term Development Plan developers to be accountable, effective and efficient.

\section{LITERATURE REVIEW Public Policy}

The government in formulating a policy means there are problems that need to be addressed. To overcome these problems, the policy needs to be implemented as soon as possible in accordance with what is expected by the government as the administration of the village administration in the hope that the village administration is well ordered on the grounds that the village data is a reference for drawing up short, medium and long term development plans . But it is known that in general the village data has not been well organized, therefore the researcher conducts an assessment to find out what causes so that the thematic data of the village has not been fully organized, whereas the government has set up a policy on the duties and functions of the Village Head, that is well organizing the village administration.

The public policy is directed towards public service. Public expectations of the services received are to be satisfied. Thus the customer decides whether the rate of service quality is good or not. The quality of public services is an interaction of various aspects. Albrecht and Zemke (Dwiyanto 
\& et. al., 2008; Hamzah, 2014), assume that service delivery to the community should pay attention to aspects of service system, human resources service providers, service strategies, and public (costumers) called triangles of public services.

In the public context, policies in various literatures are interpreted as an action device or plan that contains public goals. Public policy is the utilization of existing resource resources to solve public and government problems. Public policy in general as a government action in the face of problems by exerting attention on who gets what, when and how. Public policy therefore serves the purpose of being a continuum of government intervention for the benefit of the powerless in society so that they can live and participate in government. Riant (2006), public policy divided into three groups, namely:

1. Macro or general public policy, or fundamental (the 1945 Constitution), Law / Government Regulation, Substitute Law, Government Regulation, Presidential Regulation, and Regional Regulation.

2. Messo or intermediate public policy, or explanation of implementation. this policy may be in the form of Ministerial Regulation, Ministerial Circular Letter, Governor Regulation, Regent Regulation, and Mayor Regulation. The policy can also be a joint decision letter (SKB) between the Minister, Governor and Regent or Mayor.

3. Micro-public policy is a policy that regulates the implementation of the policies. The form of policy is the regulations issued by the public apparatus under the Minister, Governor, Regent and Mayor.

Winarno (2005) stated that public policy, in Indonesia context, is very important and interesting when associated with the discourse of regional autonomy that is being implemented. Public policy is a policy developed by government agencies and officials, the implications of the meaning of public policy are:

1. Public policy has a specific purpose or have acts oriented to the objectives,

2. The policy contains the actions of government officials,

3. The policy is what the government actually does, So it is not what the government is still trying to do,

4. Public policy can be positive in the sense of government action on a particular issue, or is negative in the sense of government official's decision not to do something, and

5. Government policy is at least in a positive sense based on a law of force (authoritative).

Based on some of the opinions of the experts, it can be said that public policy can regulate the mechanism of follow-up action for the implementation of the achievement of goals and objectives and create a policy that leads to the condition where every officials and implementers in the organization know about whether they get support to work and implement the policy well.

\section{Policy Implementation}

Implementation of policies is the stage of execution of decisions between the formation of a policy, as well as the articles of a legislative law, the publication of an executive regulation, and the release of court decisions, or the release of regulatory standards and the consequences of policies for the community that affect some aspects of life. There are several experts introducing the policy model, namely: (1) Edward III (1984) model; Grindle (1980) model; Mazmanian \& Sabatier (1983) model; and Meter \& Horn (1975) model. In principle, there is no best model depending on its use, as in this study the author takes on the grand theory of implementation model introduced by Edward III.

Edward III (Haedar, 2010) stated that policy implementation is necessary because of policy issues that need to be addressed and solved. There are four factors that support and hinder the success of policy implementation: communication, resources, bureaucratic attitude and implementer, and organizational structure including bureaucratic work flow. The four factors are the criteria that need to exist in the implementation of a policy.

While the stages of public policy by Dunn (2005) is as follows:

1. Preparation of the Agenda

Agenda setting is a phase and a very strategic process in the reality of public policy. It is in this process that there is room to make sense of what is called a public problem and a 
priority on the public agenda is fought. If an issue succeeds in gaining status as a public issue, and getting priority on the public agenda, then the issue is entitled to allocate more public resources than other issues.

Agenda setting is also very important to determine a public issue to be raised in a government agenda. Policy issues are often referred to as policy problems. Policy issues usually arise because there has been a clash of opinions among actors regarding the direction of the action that has been or will be taken, or the conflicting views on the character of the problem. According to Dunn (2005), policy issues are the product or function of a debate about the formulation, details, explanations or judgments on a particular problem. But not all issues can enter into a policy agenda.

2. Policy Formulation

Issues that have been included in the policy agenda are then discussed by policymakers. These problems are defined then the best problem solving is sought. The solution comes from various alternatives or policy options. Similarly, with the struggle of a problem to enter into the policy agenda, in the policy formulation phase each alternative competes to be elected as the policy taken to solve the problem.

3. Policy Adoption/Legitimacy

The purpose of legitimacy is to give authority to the basic processes of government. If legitimacy actions in a society are governed by the sovereignty of the people, citizens will follow the direction of the government. But citizens must believe that the government's actions are legitimate. Support for the regime tends to diffuse - a reserve of good manners and goodwill towards government actions that help members tolerate dissonance government. Legitimacy can be managed through the manipulation of certain symbols. Where through this process people learn to support the government.

4. Policy Evaluation

In general, policy evaluations can be categorized as activities involving estimates or policy assessments that include substance, implementation and impact. In this case, evaluation is seen as a functional activity. That is, policy evaluation is not only done in the final stages, but is done in the entire policy process. Thus, policy evaluations may include the formulation stage of policy issues, proposed programs for solving policy problems, implementation and policy impact phases.

Every policy that exists need to be known and understood, because the policy can not be understood textually, but there are so many things that are contextual that are unknown by the public. This is where the role of the media as a facilitator for the transformation of information to the people. So every media must be independent or unaffected by certain political powers. In addition to the media as a tool, the community plays a role to be able to analyze each policy and be able to help draw up existing policies.

The Public Policy Implementation Model proposed by Edward III (1984) shows four variables that play an important role in achieving successful implementation. The four variables are Communication, Resources, Disposition, and Bureaucratic Structure.

\section{Communication}

According to Edward III (Agustino, 2014), communication is one of the important variables that affect the implementation of public policy, communication is crucial to the success of achieving the objectives of the implementation of public policy. Effective implementation will take place, if the decision makers know what they will do. Information known to decision-makers can only be obtained through good communication. There are three indicators that can be used in measuring the success of communication variables. Edward III (Agustino, 2014) suggests three variables:

1. Transmission. By channeling good communication, it will be possible to produce a good implementation as well. There is often a problem in the distribution of communication which is the misunderstanding (miscommunication) caused by the many levels of bureaucracy to be passed in the communication process, so the expectation is distorted.

2. Clarity. Communications received by the implementer of the policy (street-levelbureaucrats) should be clear and not confusing or ambiguous. 
3. Consistency, the commands given in the implementation of a communication must be consistent and clear to be established or executed. If the commands that are given change, it can cause confusion for the executor in the field.

Based on the results of research Edward III (Agustino, 2014) there are some common barriers commonly occurring in communication transmission: First, there is a conflict between policy implementers with orders issued by policymakers. Such disagreements will lead to direct distortions and obstacles in policy communication. Second, information is conveyed through layers of bureaucratic hierarchy. Distortion of communication can occur because of the length of the chain of information that can lead to information bias. Third, the problem of misinformation is also caused by the perception and the inability of the implementers in understanding the requirements of a policy.

\section{Resources}

The requirement of an organization is the ownership of resources. Edward III (Agustino, 2014), resources are important in the implementation of good policies. The indicators used to look at the extent to which resources affect policy implementation consist of:

1. Staff. Key resources in the policy implementation is staff or employees (street-levelbureaucrats). One of the failures that often occurs in the implementation of the policy caused by staff / employees who are not sufficient or incompetent. The addition of staff and implementors alone is not sufficient to solve the problem of policy implementation, but it requires the adequacy of staff with the necessary skills (competent and cooperative) in implementing the policy.

2. Information. In the implementation of policy, information has two forms: first, information related to how to implement the policy. Second, information on compliance data from the implementers of the established government regulations and regulations.

3. Authority. Generally, the authority must be formal in order that the order can be effectively implemented. Authority is a legitimacy for executors in implementing a politically determined policy. When authority does not exist, then the power of the implementors in the eyes of the public is not legitimized, so it can ignore the implementation of public policy. But in another context, when formal authority is available, there is often an error in seeing the effectiveness of authority. On the one hand, the effectiveness of authority is required in policy implementation; but on the other hand, effectiveness will diminish when authority is misled by the executor for his own or his group's interests.

4. Facilities. Physical facilities are important factors in policy implementation. Implementor may have sufficient, capable and competent staff, but without any supporting facilities and

\section{Disposition} infrastructure then the implementation of the policy will not succeed.

Edward III (Agustino, 2014) suggests that dispositions are among the factors that have important consequences for effective policy implementation. If the implementers have a tendency or a positive attitude or support for the implementation of the policy then there is a great likelihood that the policy will be implemented according to the initial decision. On the contrary, if the executors are negative or reject the policy, the implementation will face serious obstacles.

The form of rejection may vary as Edward III puts it in the indifference zone where policy implementers through discretion in a subtle way impede policy implementation by ignoring, delaying and other inhibitory measures. Edward III (Agustino, 2014) suggests that the factors that concern the disposition in policy implementation consisting of:

1. Appointment of bureaucracy. Disposition or executive attitude will create real barriers to policy implementation if existing personnel do not implement the policies desired by higher officials. Therefore, the appointment and selection of personnel implementing the policy should be dedicated to the established policy, more specifically to the interests of the community.

2. Incentives are one of the recommended techniques for addressing the problem of policymakers' attitude by manipulating incentives. Basically, people move on their own 
interests, then manipulating incentives by policymakers influenced based on the actions of policy implementers. By way of adding a profit or a certain cost may be a driving factor that makes the executors run the command properly. This is done as an effort to fulfill personal or organizational interests.

\section{Bureaucratic Structure}

According to Edward III (Agustino, 2014), the one which influences the success rate of public policy implementation is bureaucratic structure. Bureaucracy is one of the most frequent institutions even as a whole executing activity. Edward III (Winarno, 2005) stated that there are two main characteristics of bureaucracy, Standard Operating Procedure (SOP) and Fragmentation. Standard Operating Procedure (SOP) is a development of the internal demands of time certainty, resources as well as the need for uniformity in a complex and wide-ranging work organization. In the end, the implementation of the policy is a process of implementing policies through operational measures to generate the desired outcomes.

\section{VILLAGE GOVERNMENT ADMINISTRATION}

The administration philosophy stated that administration is a whole process of cooperation between two or more human beings based on a certain rationality to achieve a predetermined goal (Siagian, 2008). Thus, basically, administration is the activity of two or more human beings based on certain rationality through a cooperation within an organization to achieve a predetermined goal. The linkage with the administration of village administration can be well realized, if all elements can create good cooperation.

Although there is a change of law, but the basic principles as the basis for regulating the village:

1. Diversity, which means that village terms can be adapted to socio-cultural conditions and the origin of local communities. This means that the pattern of governance and development implementation in the village must respect the value system prevailing in the local community, and must still heed the shared value system in the life of the nation and state.

2. Participation, which means that government administration and rural development must be able to realize the active role of society so that society always have and take responsibility for the development of life together as fellow villagers.

3. Original autonomy, meaning that the village officials have the authority in organizing and managing the local community, but must be held in the perspective of state administration which always keep up with the times.

4. Democratization, meaning that government administration and development implementation in the village must accommodate the aspirations of the people who are articulated and aggregated through BPD (Village Consultation Bodies) and the community focused institution as partners of the village government.

5. Comunity empowerment, meaning that the governance and development in the village is aimed at improving the living standards and welfare of the people through the establishment of policies, programs and activities that are in line with the essence of the problems and priorities of the community's needs.

Minister of Home Affairs Regulation No. 32 of 2006 on Village Administration Guidelines explains what is meant by village administration, that is the whole process of recording data and information of administrative activities in village administration books. Types of village administration include:

1) General Administration is a data and information recording activity regarding the activities of Village Government in General Administration Book. Forms of general administration consisted of; (1) Data Book of Village Regulation, (2) Data Book of Village Head's Decision/Regulation, (3) Data Book of Village Inventory, (4) Data Book of Village Government Apparatus, (5) Data Book of Village Owned Land, (6) Data Book of Village Land, (7) Book of Agenda; and (8) Expedition Books

2) Population Administration is a data and information recording activity regarding the population and population mutation in Population Administration Book. Forms of Population Administration 
consisted of: (1) Master Databook of Population, (2) Data Book of Population Mutation, (3) Data Book of Recapitulation of Population End of Month: and (4) Data Book of Temporary Population.

3) Financial Administration is the data and information recording activity regarding the financial management in Book of Finance Administration. Forms of Village Finance Administration consisted of: (1) Book of Budget Reception, (2) Book of Routine Expenditure Budget: (3) Book of Development Budget; (4) General Cash Books; (5) Auxiliary Book of Budget Reception, (6) Auxiliary Book of Routine Expenditure Budget: (7) Auxiliary Book of Development Budget 4

4) Development Administration is a data and development information recording activity that will be, is and has been carried out in the Development Administration Book. Forms of Development Administration consisted of: (1) Book of Development Plan, (2) Book of Development Activity, (3) Book of Project Inventory; and (4) Book of Cadres for Community Development / Empowerment

5) Village Consultative Administration or so-called BPD is the data and information recording activities on BPD. Forms of Administration of Village Consultative Board (BPD) consisted of: (1) Data Book of BPD Budget, (2) Data Book of BPD Decision/Regulation, (3) Data Book of BPD Activity, (4) Agenda Book of BPD:

In implementing the village administration, Regional and District Government are obliged to

foster and supervise it. Development and Supervision of Regional Government includes:

a. Establish Arrangements relating to Village Administration.

b. Provide Technical Guidelines for the Implementation of Village Administration.

c. Evaluate and Supervise the Implementation of Village Administration, and

d. Provide guidance, Supervision and Consultation of Village Administration Implementation.

While the guidance and supervision conducted by the District Government include:

a. Facilitate Village Administration

b. Supervise the Village Administration; and

c. Provide guidance, supervision and consultation of Village Administration Implementation Government Regulation No. 72 of 2005 regarding the Villages explains that the composition of village government organizations are: Village Governance consists of Village Government and Village Consultative Body (BPD). Furthermore, the Village Government includes Village Head and Village Apparatus. While the Village Apparatus consists of Village Secretary and other Village Apparatus.

\section{RESEARCH METHODOLOGY}

The type of this research is qualitative approach. This research is carried out in Peana Village, Pipikoro District, Sigi Regency, Central Sulawesi Province. The focus of this research are:

1. Communication, meaning the government apparatus communicates by conducting socialization, coordination to the community about the duties and functions of village government that must be implemented.

2. Resources, meaning the ability and skills of village officials on the implementation of duties and functions of the village head. Policy implementation needs to support the resources of both human resources and non-human resources.

3. Disposition, this includes three important things, namely (a) the villagers' response to the policy of the duties and functions of the village head in administering the village administration (b) cognition, i.e., the understanding of the policy; and (c) the intensity of disposition that is the value preference that the village head has for his duties and functions.

4. The bureaucracy structure is important to support the successful implementation of tasks and functions if each organization takes into account the standard operating procedures (SOP), based on a mindset that place SOP as a guideline for every village official to act.

Data collection techniques and data validation include observation, interviews, documentation techniques of trust, transparency, dependence, certainty. Data analysis techniques are data collection phase, data reduction phase, data presentation stage and drawing conclusion (Miles \& Huberman, 1992).

\section{RESEARCH RESULTS AND DISCUSSION}




\section{Profile of Peana Village, Pipikoro District, Sigi Regency, Central Sulawesi Province}

The intersections of Peana peoples that are geographically isolated from outside cultures are strongly influenced by changes in the political, economic, cultural and trust systems developed by the Peana people. Although i tis not as intensive as coastal areas, the intersection has been going on for a long time, which consequently can be seen from various social aspects in Peana society today. Peana Village consists of two sub-villages, consisting of Hamlet I Bola and Hamlet II Ntenunu. From the two hamlets, Hamlet I Bola is the most populated hamlet, while Hamlet II is the least populated. The Peana Village community is predominantly Christian-Protestant (Salvation Army). This village is inhabited by the Topo Uma ethnic and uses the Uma language in everyday interactions. The village head of Pena is now named Oriza K. Djiloy, staffed by 8 staff spread to various fields. In addition to the staff there are also 9 Neighbourhood Head and secretaries (Kantor Desa Peana Kecamatan Pipikoro, 2018).

To arrive in this village using a two-wheeled vehicle, one must travel for 2 hours journey or equivalent to $30 \mathrm{~km}$ from the Tomua village of Southern Kulawi district. The road conditions are bad, muddy dirt roads, with an average width of 1 meter. Down the slope and there is a steep cliff beside it. Considering the condition of the research area, the government should have empathy for the development of the village, both in relation to infrastructure and facilities and infrastructure that support the development of the village in a more advanced direction at least in the same level as the already developed villages. Meanwhile, the Dean of Faculty of Social and Political Sciences, Padjadjaran University, Dr. R. Widya Setiabudi Sumadinata, SIP., SSi., MT., MSi (Han), said that rural areas constitute the largest part of Indonesian society. For that reason, this rural problem needs serious attention in order to increase the strength of the nation (Sumadinata, 2017).

\section{Policy Implementation on the Duties and Functions of Village Heads in Villages Administration of Peana Village, Pipikoro district, Sigi Regency, Can be Seen from the Aspects of Communication, Resources, Disposition, Bureaucracy Structure. Communication Aspect}

Any organization definitely requires communication not only to leaders and members, but all who become partners in carrying out activities for achievement of goals. Basically, communication is the process of delivering messages or information from one party (communicator) to the other party (communicant) in the form of discussion and symbols by using the channel. Pace (2005) defines organizational communication as a show and interpretation of messages between communications units that are part of a particular organization. Edward III in the policy process means the process of delivering policy information from policy makers to policy implementers.

Communication policy has several dimensions, including the dimensions of transformation (transmission), clarity and consistency. The meaning of information related to the policy regarding the Tasks and Functions of Village Head in Village Administration of Peana Village, Pipikoro, Sigi, is to be submitted to the implementor so that policies taken can be known what the content, goals, direction, the right target groups as clarity positions as in Village Law No.6 of 2014 and correctly prepared and implemented as the expectation. Distribution of good communication will be able to produce a good implementation as well. Often there is a problem in the distribution of communication which is the misunderstanding caused by the many levels that must be passed in the communication process. Consistency and clarity are needed in a communication so that a policy can be implemented properly

In relation to the policy of administration of the village administration, cooperation should be done by creating communication with all parties so that village administration can be fulfilled and can be well implemented. How the application of policy communication to the target clearly and consistently so as to achieve maximum results can be observed through the opinion of informants interviewed by researchers who stated that the form of communication executed by the village head is still limited to internal needs by conveying staff about the policy, but the village head has not follow it up by disseminating to all related elements and not yet coordinating, so that village administration has not been fully implemented.

Directorate General of Rural Area Development of Ministry of Village, Development of Diasdvantaged Regions, and Transmigration Prof. Dr. Ir. Ahmad Erani Yustika, when reading the Scientific Oration at the 59th Anniversary of the Faculty of Social and Political Sciences (FISIP) Padjadjaran University in Bale Sawala Unpad Rectorate Building Jatinangor campus, 2017 (Yustika, 
2017) explains that other important elements of village development are local government, central government, and universities. He added, without it, by just leaving it to the village or region, the development will be slow. Therefore, it is clear that the importance of collaborative governance on village and rural areas issues.

\section{Resources Aspect}

Resources are one of the success factors in implementing policies. Although the policy has been clearly communicated and consistent, but if the implementor lacks the resources to implement the policy then the implementation of the policy can not be achieved. Resources aspect have an important role in the implementation of duties and functions of the village head in the village administration, both human resources and financial resources. In relation to this, the results of interviews with informants explained that The village head still lacks the understanding of effective administration, as does the village apparatus. This information requires cooperation from various parties to provide assistance.

Implementation of the policy will not succeed without the support of qualified human resources. The quality of human resources is related to the skills, dedication, professionalism and competence in their field, while the quantity related to the amount of human resources is sufficient to cover the entire target. In addition to human resources, other important things are non-human resources, one of which is the facility. Proper facilities or infrastructures, such as buildings, land and office equipment will support the successful implementation of the policy. Based on the results of the interviews, the facility resources in Peana Village to support the tasks and functions of the village head are inadequate, it is necessary to improve the facilities and infrastructure to support the duties and functions of the village head in administering the village administration. The next thing to support is budget resources. However, it is known that the Village Fund budget is ready, but the allocation to meet village data has not been maximized, so administrative village data are not yet ready to be used for short, medium and long term development program.

\section{Disposition}

Disposition is no less important in the implementation of a policy. In this case the relevant agencies or implementing agencies in carrying out coordination of control between implementers in the implementation of policy tasks and functions of village heads in village administration. Edaward III (Subarsono, 2005) stated that disposition is the character and characteristics possessed by the implementor, such as commitment, honesty, democratic nature, and so forth. If the implementor has a good disposition, then he or she will be able to run the policy as well as the policy maker wants. However, when the implementor has different attitudes or perspectives with the policymaker, then the policy implementation process also becomes ineffective.

To see this, an interview was conducted with the informants of Peana Village community to explain that the village administration was not well organized yet, but there was an attitude from the village head to head towards improvements to fix all the shortcomings, whether it was the lack of himself or the Peana Village apparatus itself. The village head always holds the commitment, the willingness to make improvements, ie there is a willingness to promote the village for the sake of the village community, especially if there is criticism and suggestion of the village head must consider, that also, if there is something unkown by village head, he would not hesitate to ask for help of people in the work environment. All of this requires a collaborative leadership to build an independent village.

\section{Bureaucratical Structure}

Bureaucratic structure is a description of the duties and responsibilities and cooperation between implementers in the implementation of a policy. One of the elements that need to be considered in relation to bureaucratic structure is the Standard Operating Procedure (SOP) and fragmentation. The interview results prove that in the implementation of duties and functions of the village head in the administration of village administration in Peana village is still guided by the standard operating procedures that have been regulated in the laws and regulations of the government, although there is no specific operational standards created by the Peana Village government itself.

Implementation of a complex policy demands the cooperation of many parties. When the bureaucratic structure is not conducive to the implementation of a policy, it will lead to ineffectiveness and impede the course of policy implementation. The implementation of duties and functions policy of 
village head in village administration of Peana Village from the aspect of bureaucracy structure as stated by the informant that as the public figure of the bureaucracy structure in the administration of the village run well, but limited to the service to the community, such as the people taking care of the letters with easy stages, starting from the neighbourhood level, then the village government, to districts.

Any bureaucracy of its kind, whether government or private, always guided by binding rules in carrying out its duties, as well as the bureaucracy in Peana Village. In addition, as a bureaucratic organization to achieve good performance, coordination and responsibility are required in the implementation of its duties. Bureaucratic Structure in Implementation of duties and functions of the village head in the administration of village administration in the village of Peana in terms of responsibility goes well and full of responsibility, but still limited to the provision of services to the community. The bureaucratic structure plays an important role in achieving effective and efficient policy performance. Because the bureaucratic structure is a series of daily activities needed to achieve organizational goals that are distributed through the means that have been determined and considered as an official task.

\section{CONCLUSION}

Based on the research results on the implementation of duties and functions policy of Village Head in village administration of Peana Village, it can be concluded that things that influence the implementation of duties and function policy are four factors, that is communication aspect, resource aspect, disposition aspect and bureaucratic structure aspect. Based on the four aspects, it is concluded that the implementation of duties and functions policy of Village Head in village administration of Peana Village is not yet effective. If viewed from aspect of communication, it is not yet running well, inadequate resources in terms of quality of human resources are minimal, and the disposition has not been maximized. However, when viewed from the aspect of bureaucratic structure, it has been effective, because in the implementation of duties and functions of the village head in village administration of Peana Village has been guided by standard operating procedure (SOP), as well as the existence of bureaucratic structure in the policy implementation.

\section{SUGGESTIONS}

1. The Peana village head and apparatus is expected to be able to socialize the policy of duties and functions of the village head to the community, so that the community will and give the data.

2. The local government is expected to provide training to village apparatus in improving the quality of human resources in Peana Village, so that village officials understand good administrative governance procedures.

3. The government is expected to be able to pay attention to the facilities and infrastructure in the village office that is needed to run the functions and duties of the village head and to meet the budget required for the progress of the village.

4. The village head is expected to maximize the implementation of village administration in Peana Village for the sake of village progress.

\section{REFERENCES}

Agustino, L. (2014). Dasar-Dasar Kebijakan Publik. Bandung: Alfabeta.

Dunn, W. N. (2005). Pengantar Analisis Kebijakan Publik. Yogyakarta: Gajah Mada University Press.

Dwiyanto, A., \& et. al. (2008). Reformasi Birokrasi Publik di Indonesia. Yogyakarta: Gajah Mada University Press.

Edward III, G. C. (1984). Public Policy Implementation. London: Jai Press.

Grindle, M. S. (1980). Politics and Policy Implementation in the Third World. New Jersey: Princeton University Press.

Haedar. (2010). Implementasi Kebijakan: Apa, Mengapa dan Bagaimana. Jurnal Ilmu Administrasi Publik. Jurnal Pemikiran Dan Penelitian Administrasi Publik.

Hamzah, O. S. (2014). Perilaku Birokrasi Pemerintah dalam Pelayanan Kesehatan di Kota Makassar. Urnal Ilmiah Ilmu Admnistrasi Publik: Jurnal Pemikiran Dan Penelitian Administrasi Publik.

Kantor Desa Peana Kecamatan Pipikoro. (2018). Profil Desa. 
Mazmanian, D., \& Sabatier, P. A. (1983). Implementation and Public Policy. Glenview: Scott.

Meter, V., \& Horn, V. (1975). The Policy Implementation Process; A Conceptual Fremework. Amsterdam: Van Meter and Van Horn Administration \& Society.

Miles, M. B., \& Huberman, A. M. (1992). Analisis Data Kualitatif. Jakarta: Universitas Indonesia Press.

Pace, W. (2005). Komunikasi Organisasi. Strategi Meningkatkan Kinerja Perusahaan. Bandung: Remaja Rosdakarya.

Peraturan Mentri dalam Negeri Nomor 32 Tahun 2006 tentang Pedoman Administrasi Desa.

Peraturan Mentri dalam Negeri Nomor 47 Tahun 2016 tentang Administrasi Pemerintahan Desa.

Peraturan Mentri dalam Negeri No.72 Tahun 2005, tentang Desa

Peraturan Mentri Nomor 2 Tahun 2017 tentang Penyelenggaraan Administrasi Desa.

Riant, N. D. (2006). Kebijakan Publik; Formulasi, Implementasi, dan Evaluasi. (Cet. Pertama). Jakarta: Elex Media Komputindo.

Siagian. (2008). Teori Motivasi dan Aplikasi. Jakarta: Bina Aksara.

Subarsono, A. G. (2005). Analisis Kebijakan Publik. Jakarta: Pustaka Pelajar.

Sudirman. (2004). Interaksi dan Motivasi Belajar Mengajar. Jakarta: Raja Grafindo Persada.

Sumadinata, W. S. (2017). Dekan FISIP Unpad Dr. R. Widya Setiabudi Sumadinata, SIP., SSi., MT., MSi (Han), mengatakan bahwa perdesaan merupakan bagian terbesar dari masyarakat Indonesia. Untuk itu, masalah perdesaan ini memerlukan perhatian serius agar dapat meningkatkan kekuatan - Bandung: Universitas Padjadjaran. Retrieved from www.unpad.ac.id/agenda/orasi-ilmiahmenristekdikti-di-dies-natalis-ke-59-unpad/

Undang-Undang No. 6 Tahun 2014 tentang Desa.

Winarno, B. (2005). Kebijakam Publik Teori \& Proses. Jakarta: Buku Kita.

Yustika, A. E. (2017). Dirjen Pembangunan Kawasan Perdesaan Kementerian Desa, Pembangunan Daerah Tertinggal, dan Transmigrasi, Prof. Ahmad Erani Yustika saat membacakan Orasi Ilmiah pada peringatan Dies Natalis ke-59 Fakultas Ilmu Sosial dan Ilmu Politik (FISIP) Universitas Pad. Bandung: Universitas Padjadjaran. Retrieved from www.unpad.ac.id/agenda/orasi-ilmiahmenristekdikti- di-dies-natalis-ke-59-unpad/ 